\title{
Modification of blood pressure in postmenopausal women: role of hormone replacement therapy
}

This article was published in the following Dove Press journal:

International Journal of Women's Health

II August 2014

Number of times this article has been viewed

\section{Marianna Cannoletta Angelo Cagnacci \\ Institute of Obstetrics and Gynecology, Department of Medical and Surgical Sciences of the Mother, Child and Adult, University of Modena and Reggio Emilia, Modena and Reggio Emilia, Emilia-Romagna, Italy}

Correspondence: Angelo Cagnacci Ginecologia e Ostetrica, Azienda Policlinico di Modena, Via del

Pozzo 7I, 4I I 24 Modena, Italy

Tel +39059422 45I I

Email cagnacci@unimore.it

\begin{abstract}
The rate of hypertension increases after menopause. Whether estrogen and progesterone deficiency associated with menopause play a role in determining a worst blood pressure (BP) control is still controversial. Also, studies dealing with the administration of estrogens or hormone therapy (HT) have reported conflicting evidence. In general it seems that, despite some negative data on subgroups of later postmenopausal women obtained with oral estrogens, in particular conjugated equine estrogens (CEE), most of the data indicate neutral or beneficial effects of estrogen or HT administration on BP control of both normotensive and hypertensive women. Data obtained with ambulatory BP monitoring and with transdermal estrogens are more convincing and concordant in defining positive effect on BP control of both normotensive and hypertensive postmenopausal women. Overall progestin adjunct does not hamper the effect of estrogens. Among progestins, drospirenone, a spironolactone-derived molecule, appears to be the molecule with the best antihypertensive properties.
\end{abstract}

Keywords: hormone replacement therapy, estrogen, progestin, blood pressure, menopause, hypertension

\section{Introduction}

Hypertension is a continuous, non-occasional state of elevated blood pressure (BP). BP increases with age. As a consequence of longer life expectancy and modern lifestyle, the prevalence of hypertension is expected to increase..$^{1}$ While diastolic BP starts to increase earlier, systolic BP starts to increase after 50 years of age. The increase of systolic BP is a higher health risk. A higher incidence of cardiovascular and cerebrovascular diseases is observed respectively 10 and 20 years after BP increase. ${ }^{2}$ A 2012 World Health Organization report shows that the rise of BP causes $51 \%$ of deaths from stroke, and $45 \%$ of deaths from coronary artery diseases. ${ }^{3}$

There are sex differences in the development of hypertension. The National Health and Nutrition Examination Survey (NHANES) shows that, prior to 45 years of age, prevalence of hypertension is higher in men than in women. From 45 to 54 years and from 55 to 64 years of age, the percentage of hypertensive men is similar to that of hypertensive women. After 65 years of age, BP levels increase faster in women than in men. ${ }^{4}$

It has been suggested that sex steroids protect fertile women from hypertension, and that gonadal steroid withdrawal may play a role in the modifications of BP control. ${ }^{5}$ In fact, the role played by steroid withdrawal at menopause is still controversial. 


\section{Menopause and BP}

Cross-sectional studies show that hypertension is two times more prevalent in post- than in pre-menopausal women, regardless of age and body mass index (BMI), ${ }^{6}$ and that this prevalence is reduced by the use of hormone therapy (HT). ${ }^{7}$ In a cross-sectional Italian investigation performed on 22,250 women around the menopause, the postmenopausal status doubled the risk of developing hypertension. ${ }^{8}$ Similar results were observed in a study on hypertension prevalence in menopause in the Italian population, a cross-sectional investigation on 18,326 women from 46 to 59 years of age. ${ }^{9}$ Regardless of confoundings in the study, systolic and diastolic BP were slightly but significantly higher $(+3.4$ and $+3.1 \mathrm{mmHg}$, respectively) in post- than in pre- and perimenopausal women. A recent article evaluating 908 female residents aged 45-54 years in a Prague district linked the postmenopausal BP rise to the increase of BMI, ${ }^{10}$ which is commonly observed in the menopausal transition. ${ }^{11-13}$

In spite of these evidences, other studies could not find a direct correlation between the menopause event and the development of hypertension. In a 16-year study performed on 525 Italian pre- and post-menopausal women, systolic BP was found to be related to age, but not to hormonal status. ${ }^{14}$ Similarly, no correlation between menopausal status and hypertension emerged in a cross-sectional study on more than 22,000 Japanese post-menopausal women, once the data were adjusted for age and time since menopause. ${ }^{15}$ Similarly, a 16-year longitudinal study on more than 9,000 women aged 18-70 years showed that the worst BP profile observed in postmenopausal women was not the consequence of the menopausal status. ${ }^{16}$

\section{Sex steroid effects on blood vessels}

Experimental data indicate that gonadal steroids may regulate blood vessel functions. Estrogens influence the activity of endothelial cells, via genomic and non-genomic signaling. By binding to $\mathrm{ER} \alpha$, estrogens increase the production of vasodilating agents such as nitric-oxide, prostacyclin and prostaglandin E2 and reduce oxidative stress and proinflammatory cytokines. ${ }^{17-20}$ The binding of estrogens to ER $\beta$ modulates the expression of ER $\alpha$ and antagonizes some of the beneficial effects of estrogens. ${ }^{21}$ Interestingly, ER $\beta$ are overexpressed in women with a higher incidence of coronary artery disease. ${ }^{22}$ In addition to effects mediated by endothelial cells, estrogens may vasodilate vessels via an influence on calcium-dependent potassium channels, and a block of calcium channels. ${ }^{23,24}$ Progesterone itself, when binding to its receptor, may exert vasodilating effects, ${ }^{25}$ depending on the vessel and on the levels of the hormone, ${ }^{26,27}$ sometimes antagonizing the effect of estrogens. ${ }^{27}$

Studies in vivo have shown that estrogens administered acutely and in high doses exert vasodilating effects, ${ }^{28-34}$ which are also observed, ${ }^{35-38}$ although inconsistently, ${ }^{39-40}$ with the prolonged administration of lower estrogen doses. This endothelium-mediated dilating effect of estrogens disappears in women with endothelium alterations ${ }^{41}$ and appears to decrease with time since menopause, being lost several years after the menopause. ${ }^{41,42}$ In this situation, the administration of estrogens appears to be deleterious by favoring a shift towards the production of proinflammatory cytokines. ${ }^{42}$

The concomitant administration of progestins may antagonize the vasodilating effect of estrogens. Conflicting data have been reported for medroxyprogesterone acetate (MPA) $)^{43,44}$ and norethisterone acetate (NETA), ${ }^{45,46}$ and more neutral effect for desogestrel (DSG) ${ }^{47}$ and physiological doses of progesterone..$^{48}$

Beside the direct effect on endothelial cells, complex modulation of the renin-angiotesin-aldosterone axis, ${ }^{49-53}$ as well as of the adrenergic stimulus ${ }^{41,54,55}$ should be taken into consideration when evaluating the possible influence of sex steroids or of their administration on the control of BP.

\section{HT and BP}

On the basis of actual knowledge it can be hypothesized that in postmenopausal women the administration of HT influences BP control. This effect may vary depending on the type of estrogen used, its dosage, its route of administration, and the progestin molecule eventually associated. Recent versus late postmenopausal women may also differ in their response. Indeed, there are a relevant number of studies dealing with the interaction between HT and BP regulation, and the results are often conflicting. ${ }^{56}$

The present review summarizes actual knowledge of the effect of postmenopausal HT in modifying BP control. The effect of HT is presented separately for normotensive and hypertensive women. For each condition, data obtained with estrogen alone, estrogen plus progestin and the effect of different progestins are summarized. Data obtained with office and ambulatory blood pressure measurement are presented in sequence, grouped according to their concordance. Concordant data are presented in chronological order with cross-sectional studies preceding randomized clinical trials. Studies were retrieved by PubMed search and limited to the years 1980 to 2013. The research was implemented using references cited in selected articles. Search terms were menopause, blood pressure, hypertension, hormone therapy, 
estrogen, and progestin. Only articles in the English language were retrieved.

\section{HT in normotensive women HT with estrogens alone in normotensive women}

In the Rancho Bernardo study, a cross-sectional investigation of 1,044 postmenopausal women, the use of conjugated equine estrogens (CEE) for ten years seemed to induce a better BP control than in non-users. ${ }^{57}$

These data were not confirmed by some clinical trials (Table 1). In the Women's Health Initiative (WHI), a placebo-controlled trial performed on more than 10,000 hysterectomized women $50-79$ years of age with a mean age of 63.6 years at enrollment, $0.625 \mathrm{mg} / \mathrm{d}$ of CEE induced a small but significant increase of systolic BP. ${ }^{58}$

Similar data were obtained in a 9-month prospective comparative study on 160 normotensive postmenopausal women, aged 52 years, where administration of CEE was associated with a marked elevation of BP. ${ }^{59}$ During CEE administration, systolic BP increased more than $15 \mathrm{mmHg}$ in about $20 \%$ of women treated, and diastolic BP increased more than $15 \mathrm{mmHg}$ in $10 \%$ of the women. ${ }^{59}$ Negative effects of CEE on BP were further published by the same authors in another study. ${ }^{60}$ Interestingly, the administration of only estrone sulfate decreased BP. Because $50 \%$ of CEE is made by estrone sulfate, the negative effect of CEE on
BP may be due to equiline derivatives $(30 \%-40 \%)$ or other components that do not naturally occur in the human. In the Estrogen in the Prevention of Atherosclerosis Trial (EPAT), a placebo-controlled trial on 222 normotensive or hypertensive postmenopausal women, micronized estradiol (1 mg) instead of CEE was orally administered. Different effects were observed between younger and older women. In the former, systolic BP slightly increased; in the latter, diastolic BP slightly decreased. ${ }^{61}$

Several studies have placed their primary objective on the effect that estrogens exert on the control of BP throughout the 24-hour period (Table 1). These studies, although smaller in sample size, are stronger in terms of measurement, and more reliable than studies in which BP evaluation was performed by single office measurement and as a secondary objective of the study. In these studies, oral estrogens either increased (E2) ${ }^{62}$ or did not modify (CEE) 24-hour BP values. ${ }^{63,64}$ Transdermal estradiol instead was reported to decrease ambulatory BP in almost all studies reviewed (Table 1).

In 90 normotensive women 30 to 59 years of age in surgical menopause, randomized to a 6-month treatment with oral (combination of E2, estrone [E1], and estriol [E3]) or transdermal estrogens, nighttime systolic and both nighttime and daytime diastolic BPs decreased by about $4 \mathrm{mmHg}$ in the transdermal but not in the oral estrogen group. ${ }^{63}$ In a placebocontrolled study performed in 18 normotensive healthy postmenopausal women, transdermal E2 $(50 \mu \mathrm{g} /$ day per 8 weeks $)$

Table I Clinical trials investigating the effect of estrogens on blood pressure of normotensive postmenopausal women

\begin{tabular}{|c|c|c|c|c|c|c|c|}
\hline $\begin{array}{l}\text { Source of } \\
\text { trial }\end{array}$ & $\begin{array}{l}\text { Year of } \\
\text { trial }\end{array}$ & $\begin{array}{l}\text { Age of } \\
\text { subjects }\end{array}$ & $\begin{array}{l}\text { Number of } \\
\text { subjects }\end{array}$ & $\begin{array}{l}\text { Route of } \\
\text { administration } \\
\text { of estrogens }\end{array}$ & $\begin{array}{l}\text { Estrogens } \\
\text { administered }\end{array}$ & $\begin{array}{l}\text { BP measurement } \\
\text { mode }\end{array}$ & Effects of estrogens \\
\hline $\mathrm{WH} I^{58}$ & 2004 & 63.6 & $\sim 10,000$ & Oral & CEE 0.625 mg & Office & $\uparrow$ systolic BP \\
\hline Wren ${ }^{59}$ & $|98|$ & 52 & 160 & Oral & $\begin{array}{l}\text { El sulphate + } \\
\text { CEE } 0.625 \mathrm{mg}\end{array}$ & 24-h & $\begin{array}{l}\downarrow \mathrm{BP} \\
\uparrow \mathrm{BP}\end{array}$ \\
\hline EPAT $^{61}$ & 2008 & 61 & 222 & Oral & E2 I mg & Office & $\begin{array}{l}\uparrow \text { systolic BP in younger } \\
\downarrow \text { diastolic BP in older }\end{array}$ \\
\hline Akkad ${ }^{63}$ & 1997 & $30-59$ & 90 & $\begin{array}{l}\text { Transdermal } \\
\text { Oral }\end{array}$ & $\begin{array}{l}\text { E2 } 0.05 \mathrm{mg} \\
\mathrm{E} 2+\mathrm{E} 3+\mathrm{El}\end{array}$ & 24-h & $\begin{array}{l}\downarrow \text { nocturnal systolic BP } \\
\downarrow \text { diastolic BP } \\
=24-\mathrm{h} \mathrm{BP}\end{array}$ \\
\hline Cardoso ${ }^{62}$ & 2011 & $45-60$ & 47 & Oral & $\mathrm{E} 2 \mathrm{~V} \mathrm{I} \mathrm{mg}$ & 24-h & $\begin{array}{l}\uparrow \text { systolic BP } \\
\uparrow \text { diastolic BP }\end{array}$ \\
\hline Vongpatanasin ${ }^{64}$ & 2001 & 53 & 12 & $\begin{array}{l}\text { Transdermal } \\
\text { Oral }\end{array}$ & $\begin{array}{l}\text { E2 } 0.2 \mathrm{mg} \\
\text { CEE } 0.625 \mathrm{mg}\end{array}$ & 24-h & $\begin{array}{l}\downarrow 24-h \mathrm{BP} \\
=24-\mathrm{h} \mathrm{BP}\end{array}$ \\
\hline Cagnacci $^{65}$ & 1999 & 53.5 & 18 & Transdermal & E2 $0.05 \mathrm{mg}$ & 24-h & $\begin{array}{l}\downarrow \text { nocturnal systolic BP } \\
\downarrow \text { nocturnal diastolic BP } \\
\downarrow \text { nocturnal mean BP }\end{array}$ \\
\hline Driul $^{66}$ & 2005 & 51.3 & 46 & Transdermal & E2 $0.05 \mathrm{mg}$ & 24-h & $\begin{array}{l}\downarrow \text { diurnal diastolic BP } \\
\downarrow \text { nocturnal diastolic BP }\end{array}$ \\
\hline
\end{tabular}

Abbreviations: 24-h, 24-hour; BP, blood pressure; CEE, conjugated equine estrogen; EPAT, Estrogen in the Prevention of Atherosclerosis Trial; EI, estrone; E2, estradiol; E2V, oral estradiol valerate; E3, estriol; WHI, Women's Health Initiative; $\downarrow$, decrease; $\uparrow$, increase; =, no change. 
magnified the nocturnal decrement of systolic (14.3 \pm 7.2 versus $9.8 \pm 6.7 \mathrm{mmHg}, P=0.0033$ ), diastolic (11.6 \pm 5.0 versus $7.5 \pm 7.3 \mathrm{mmHg}, P=0.028)$, and mean $(10.8 \pm 5.6$ versus $7.2 \pm 4.5 \mathrm{mmHg}, P=0.011) \mathrm{BP}^{65}$ In a randomized crossover placebo-controlled study on 12 normotensive women, taking transdermal E2 (200 $\mu \mathrm{g} /$ day $)$, oral CEE (0.625 mg/d), or placebo for 8 weeks, a small but significant decline of ambulatory BP was observed only with transdermal E2. ${ }^{64}$ Finally, in a group of 46 women in surgical menopause (mean age of 51 years), transdermal E2 (50 $\mu \mathrm{g} /$ day) significantly decreased diurnal and nocturnal diastolic BP in the subgroup of smokers $(n=30,65.2 \%) .{ }^{66}$

\section{HT with estrogens plus progestins in normotensive women}

Data on the effect of HT on office BP are rather conflicting; positive, neutral or negative effects have been reported. A positive effect was observed in the Coronary Risk Factors for Atherosclerosis in women (CORA) study. In this case control study, 200 consecutive pre- and post-menopausal women with incident coronary heart disease were matched with 255 controls. The study showed beneficial effects of HT on BP control of postmenopausal women with a previous cardiovascular disease. ${ }^{67}$ Similar data were obtained in the Baltimore longitudinal study on aging, an observational study on 226 healthy, normotensive postmenopausal women aged $64 \pm 10$ years, who were followed for a mean period of 5.7 years. Seventy-seven women used either oral or transdermal estrogen plus progestin, and 149 used no hormone. After 10 years of follow-up, postmenopausal women taking HT showed a smaller increase in systolic BP versus non-users (7.6 mmHg versus $18.7 \mathrm{mmHg}$ after 10 years), which was more evident in older women. ${ }^{68}$

Hassager and Christiansen ${ }^{69}$ published a summary of five trials performed with oral and transdermal estrogen associated with NETA, CPA, or micronized progesterone in about 270 women enrolled either earlier after or later after the menopause. The results of those trials indicate that any HT regimen decreases $\mathrm{BP}$, particularly diastolic $\mathrm{BP}$, of women earlier after the menopause. However, HT does not exert any effect in women later after the menopause (Table 2). ${ }^{69}$

No effect of HT on office BP was observed in two major trials, the Postmenopausal Estrogen/Progestin Interventions (PEPI) trial, ${ }^{70}$ and the Danish Osteoporosis Prevention Study (DOPS) ${ }^{71}$ (Table 2).

The PEPI trial evaluated the effects on the cardiovascular systems of 875 healthy postmenopausal women (45 to 64 years of age) of four estro-progestinic regimens
(CEE, $0.625 \mathrm{mg} / \mathrm{d}$; CEE, $0.625 \mathrm{mg} / \mathrm{d}$ plus cyclic MPA $10 \mathrm{mg} / \mathrm{d}$ for $12 \mathrm{~d} / \mathrm{month}$; CEE, $0.625 \mathrm{mg} / \mathrm{d}$ plus consecutive MPA, $2.5 \mathrm{mg} / \mathrm{d}$; or CEE, $0.625 \mathrm{mg} / \mathrm{d}$ plus cyclic micronized progesterone [MP], $200 \mathrm{mg} / \mathrm{d}$ for $12 \mathrm{~d} /$ month; or placebo alone). No significant difference in BP was observed among treatments and placebo. Similarly, there was no difference associated with the different types and doses of progestin used..$^{70}$ In the DOPS study, women taking for five years oral E2, alone or in association with NETA, did not experience a reduction of $\mathrm{BP}$ in comparison to users of placebo. ${ }^{71} \mathrm{~A}$ negative effect of HT on BP was observed in one observational and two major clinical trials (Table 2). ${ }^{72-74}$

In a recent Australian study performed on 43,405 normotensive postmenopausal women, HT use was associated with significantly higher odds of having high BP, the risk becoming higher with longer HT use. ${ }^{72}$ An increase of BP induced by HT was also observed in two major placebo-controlled trials, such as the WHI and the Heart and Estrogen/Progestin Replacement Study (HERS).

The WHI investigation evaluated 16,608 women, aged 50-79 years, taking CEE plus MPA or placebo. After two years of treatment with HT, there was an increase of $1.5 \mathrm{mmHg}$ of systolic but not of diastolic BP. Furthermore, women taking HT showed a 25\% increased risk of developing hypertension. ${ }^{73}$ In the HERS study, performed on women with cardiovascular disease, an increase of systolic $\mathrm{BP}$ was described in women receiving CEE plus MPA versus placebo. $^{74}$

More reassuring are the data of studies performed with 24-hour ambulatory BP monitoring (Table 2). Oral E2 $(1 \mathrm{mg}$ ) combined with 5 or $10 \mathrm{mg}$ dihydrogesterone (DYD) to 29 healthy normotensive postmenopausal women (mean age 52.3 years) induced a decrease of 24-hour systolic and diastolic BP in comparison to control women. ${ }^{75}$

Harvey et $\mathrm{al}^{76}$ monitored 24-hour BP of 24 normotensive postmenopausal women (median age 54 years). For each subject there were four randomized treatment phases, each lasting 4 weeks. The treatments were $0.625 \mathrm{mg}$ estrone sulphate, $2.5 \mathrm{mg}$ estrone sulphate, $0.02 \mathrm{mg}$ ethinylestradiol, all of them associated to $10 \mathrm{mg}$ of oral MPA for 14 days, and matching placebo. Combinations containing either natural or semisynthetic estrogen reduced nighttime ambulatory $\mathrm{BP}^{76}$

In a placebo-controlled, randomized crossover study, sixteen healthy normotensive post-menopausal women (age 55 3 years) were randomized to E2 plus cyclic NETA or placebo in two 12-week periods of treatment. Ambulatory systolic and diastolic BP were reduced after 10 days of 


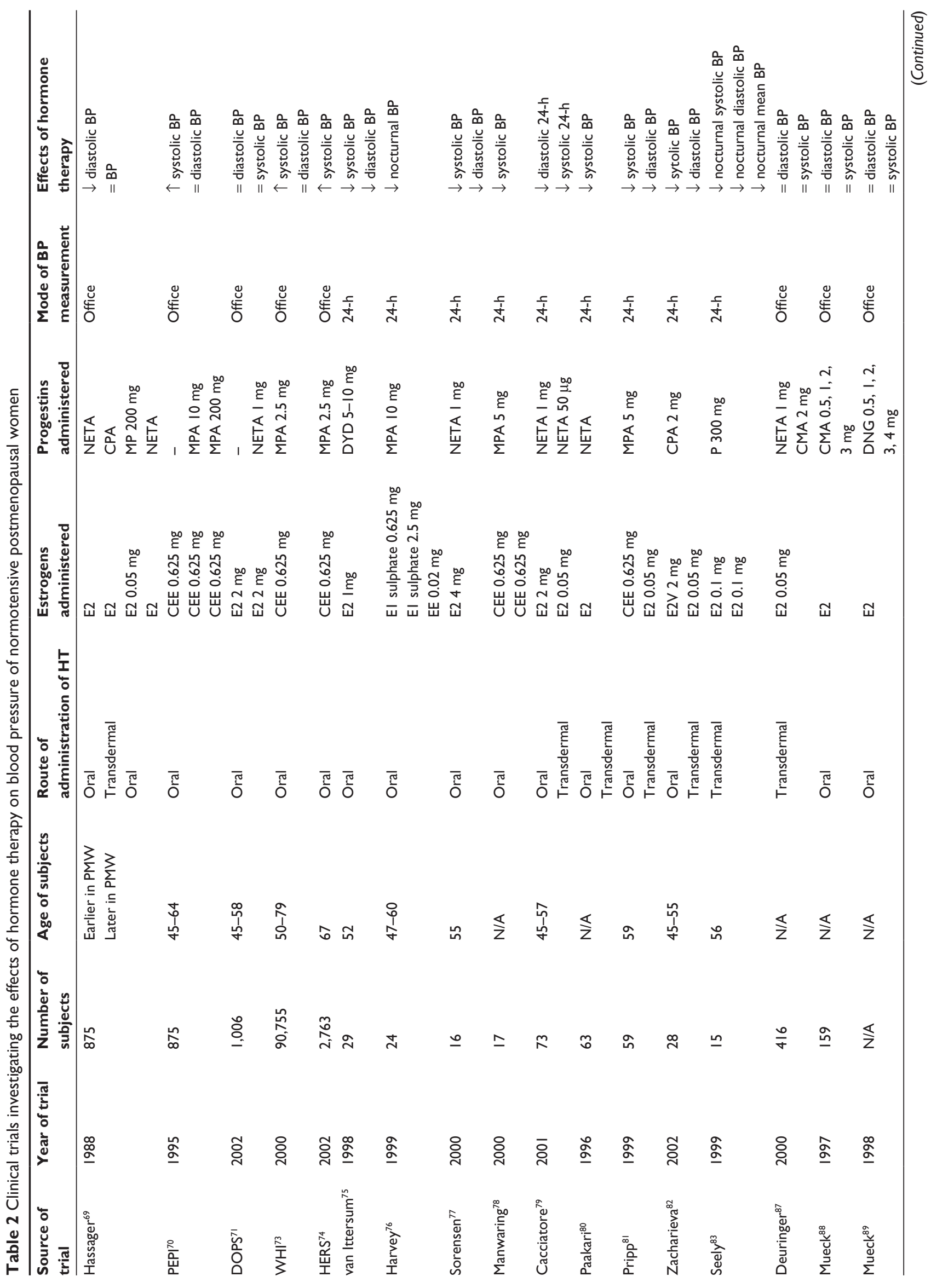




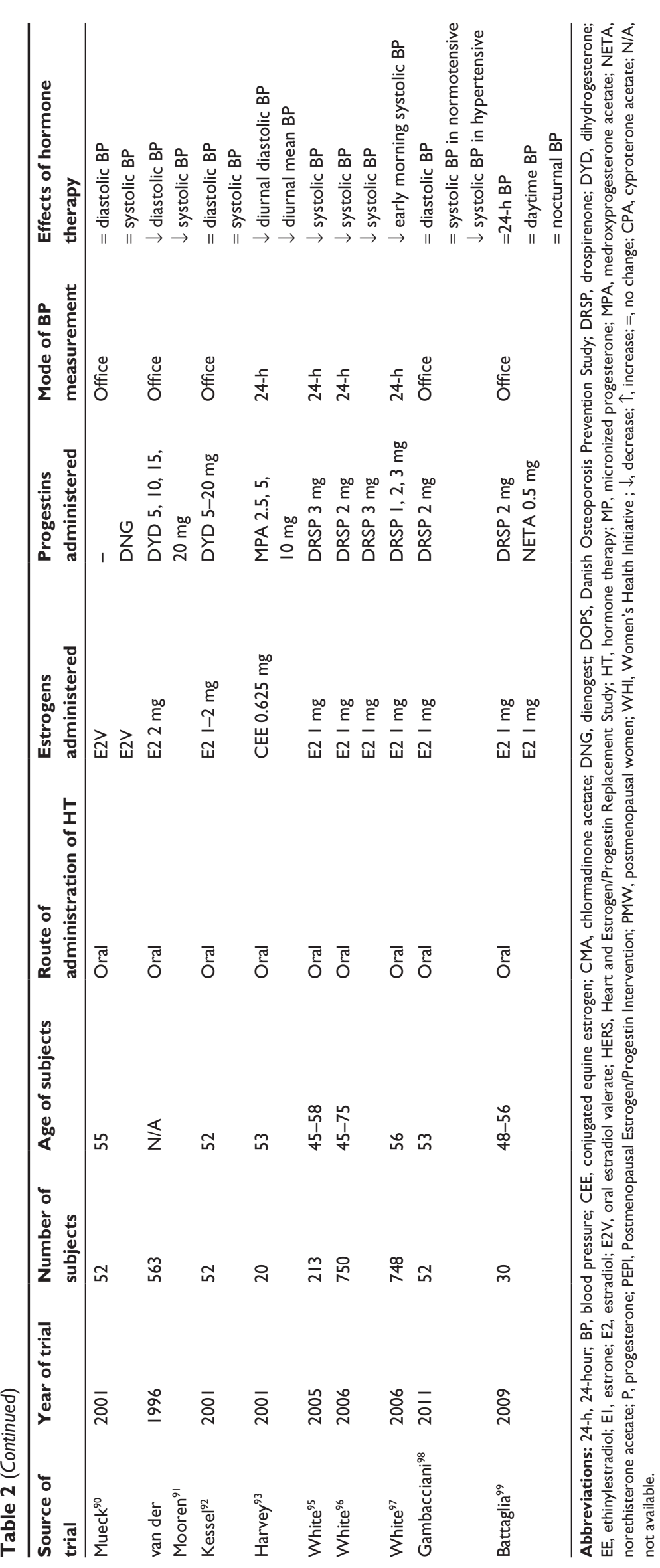


E2 (-5.1 and $-3.2 \mathrm{mmHg}$, respectively). During the addition of NETA, diastolic BP was further reduced $(-3.6 \mathrm{mmHg})$, suggesting additive BP-lowering effects of this molecule. ${ }^{77}$ In a 3-month randomized double-blind placebo-controlled crossover trial performed in 17 normotensive postmenopausal women, $\mathrm{CEE}(0.625 \mathrm{mg} /$ day $)$ alone or associated with continuous MPA ( $5 \mathrm{mg} /$ day) reduced 24-hour diastolic BP by 4 and 5 $\mathrm{mmHg}$, and systolic BP by 6 and $9 \mathrm{mmHg}$, respectively. ${ }^{78} \mathrm{In}$ a randomized study of 73 normotensive women, a significant decrease of daytime systolic BP was observed after 2 months of treatment with $2 \mathrm{mg}$ of oral $(3.8 \pm 0.2 \mathrm{mmHg})$ or $50 \mu \mathrm{g}$ of transdermal E2 $(4.0 \pm 0.3 \mathrm{mmHg})$, both sequentially associated with NETA. Mean daytime BP also decreased, both in the oral $(-1.8 \pm 0.8 \mathrm{mmHg})$ and transdermal $(-3.5 \pm 0.7 \mathrm{mmHg})$ groups. Nighttime BP remained unaffected by either treatment. ${ }^{79}$ In another study, 8 weeks of treatment with E2, oral or transdermal plus NETA, significantly reduced 24-hour systolic BP of about 4-5 mmHg. ${ }^{80}$ Sixty patients (aged 59 years) were randomized to receive $0.625 \mathrm{mg} /$ day CEE, or $50 \mu \mathrm{g}$ /day transdermal E2 or placebo for 18 days, then treatments were combined with $5 \mathrm{mg}$ MPA for an additional 10 days. After one year of therapy, night-time systolic BP decreased significantly in the $\mathrm{CEE}$ group, and both systolic and diastolic BP decreased significantly in the transdermal group. ${ }^{81}$ In 28 postmenopausal women 45 to 55 years of age, oral estradiol valerate (E2V) ( $2 \mathrm{mg}$ ) or transdermal estradiol $(0.05 \mathrm{mg}$ ) decreased 24-hour systolic BP. ${ }^{82}$ Similarly, in a placebo-controlled study the association of transdermal E2 $(0.2 \mathrm{mg} /$ day $)$ plus intravaginal progesterone ( $300 \mathrm{mg} /$ day) significantly decreased nighttime systolic, diastolic, and mean BP in 15 healthy postmenopausal women. Daytime BP followed the same trend, but was significantly lower only for mean BP. The addition of progesterone resulted in no further fall. ${ }^{83}$

\section{HT with progestins in normotensive women}

There are few studies reporting the effects of progestins on the vascular system. Progestins are a multitude of compounds, and their effect may vary depending on different pharmacokinetic properties, type of molecule, and route of administration, some negative effects being evident with the oral but not the transdermal route of administration. ${ }^{84}$ In addition, the major negative effects of progestins are related to vascular damages and injuries that are already estabilished. For this reason, conflicting evidence may be present in the literature. $^{85}$

An antihypertensive effect of oral progesterone was described in four hypertensive women and six hypertensive men. ${ }^{86}$ Several studies have investigated whether the administration of different progestins can influence BP regulation (Table 2).

\section{HT with chlormadinone acetate and NETA in normotensive women}

A study on 416 women tested the effect of chlormadinone acetate (CMA) (2 mg/day), a C21 gestagen with antiandrogenic properties, and NETA (1 mg/day), a C19 gestagen with androgenic properties, given in sequential combination (12 days/cycle) with transdermal E2 (0.05 mg/day). No significant effects were observed over the 4-month period of treatment. ${ }^{87}$

In a prospective randomized comparison, different doses of CMA $(0.5,1.0,2.0$, and $3.0 \mathrm{mg}$ per day) in association with transdermal or oral E2 were tested on 159 postmenopausal women. CMA in any dose did not modify BP. ${ }^{88}$

\section{HT with dienogest in normotensive women}

Mueck et al also tested the effects of dienogest (DNG), another C19 gestagen with antiandrogenic properties, on BP. In a randomized comparison of $0.5,1,2,3$, and $4 \mathrm{mg}$ of DNG continuously combined with E2 for 6 months, no effect of increasing DNG dose was observed on BP. ${ }^{89}$ In addition, DNG adjunct did not modify the effect exerted by E2 alone. ${ }^{90}$

\section{HT with dihydrogesterone in normotensive women}

In another study, 563 postmenopausal women were treated with micronized E2 (2 mg), sequentially combined with various doses of DYD. After 6 months of treatment, a slight but significant fall of systolic and diastolic BP was registered for the entire pooled group. After 1 year, however, the group receiving $10 \mathrm{mg}$ of DYD showed a significant rise (about 2-3 $\mathrm{mmHg}$ ) of both systolic and diastolic BP. ${ }^{91}$ In another study, DYD in doses ranging between 5 and $20 \mathrm{mg}$ per day, combined with 1 or $2 \mathrm{mg}$ of E2, appeared to be particularly neutral in terms of both metabolic and vascular effects. ${ }^{92}$

\section{HT with MPA in normotensive women}

In a double-blind crossover study, 20 normotensive postmenopausal women (median age 53 years) were randomized to four MPA treatment phases of 4 weeks each. CEE $0.625 \mathrm{mg}$ was associated with MPA $2.5 \mathrm{mg}$, MPA $5 \mathrm{mg}$, MPA $10 \mathrm{mg}$, or placebo, in the last 14 days of each 28-day treatment cycle. In comparison to placebo, during progestin administration 
there was a dose-dependent decrease of ambulatory daytime diastolic and mean BP. ${ }^{93}$

\section{HT with drospirenone in normotensive women}

Drospirenone (DRSP) is derived from spironolactone, and possesses antialdosteronic properties. This molecule can control water retention, weight increase, and BP levels. Several papers deal with the capability of DRSP to reduce BP in hypertensive women. ${ }^{94-97}$ On the other hand, clinical studies performed in normotensive women did not report any effect of DRSP on BP. In a group of 30 women randomly treated with either DRSP $2 \mathrm{mg} / \mathrm{E} 21 \mathrm{mg}$ or with NETA 0.5 $\mathrm{mg} / \mathrm{E} 21 \mathrm{mg}$, no significant difference was observed in 24-hour, daytime, and nighttime BP values. ${ }^{98}$ In another Italian study, postmenopausal women were treated with E2 (1 mg/day) plus DRSP (2 mg/day). Both systolic and diastolic BP did not vary. In subjects with systolic BP lower than $130 \mathrm{mmHg}$ at baseline, no changes in systolic $\mathrm{BP}$ values were registered, while women with baseline high-normal systolic BP (130-139 mmHg) experienced a significant BP decline. ${ }^{99}$

\section{Hypertensive women HT with estrogens alone in hypertensive women}

There are few studies dealing with the effect of estogens alone in hypertensive postmenopausal women (Table 3). In a randomized placebo-controlled study, $2 \mathrm{mg}$ or $4 \mathrm{mg}$ of micronized E2 were given to 20 normotensive and 20 hypertensive postmenopausal women. ${ }^{100}$ E2 decreased systolic and diastolic BP in both normotensive and hypertensive women. The decrease of BP was more clear in hypertensive than normotensive subjects. In a randomized double-blind placebo-controlled study performed in 30 hypertensive women (mean age 55 years), transdermal E2 (0.05 mg/day) significantly decreased 24-hour systolic and diastolic BP. Furthermore, in the non-dipper subgroup, E2 restored the expected reduction of BP at night. ${ }^{101}$

Table 3 Clinical trials investigating the effect of estrogens alone or with hormone therapy on blood pressure of hypertensive postmenopausal women

\begin{tabular}{|c|c|c|c|c|c|c|c|}
\hline Source of trial & $\begin{array}{l}\text { Year of } \\
\text { trial }\end{array}$ & $\begin{array}{l}\text { Number } \\
\text { of subjects }\end{array}$ & $\begin{array}{l}\text { Routes of } \\
\text { administration }\end{array}$ & Estrogens & Progestins & $\begin{array}{l}\text { Mode of } \\
\text { measurement }\end{array}$ & Effects \\
\hline Luotola $^{100}$ & 1983 & 40 & Oral & $\begin{array}{l}\text { E2 } 2 \mathrm{mg} \\
\text { E2 } 4 \mathrm{mg}\end{array}$ & - & Office & $\begin{array}{l}\downarrow \text { diastolic BP } \\
\downarrow \text { systolic BP }\end{array}$ \\
\hline Mercuro ${ }^{101}$ & 1998 & 30 & Transdermal & E2 $50 \mu g$ & - & 24-h & $\begin{array}{l}\downarrow \text { diastolic BP } \\
\downarrow \text { systolic BP }\end{array}$ \\
\hline Kornhauser ${ }^{104}$ & 1997 & 55 & $\begin{array}{l}\text { Oral } \\
\text { Oral +im }\end{array}$ & $\begin{array}{l}\text { Estradiol valerate } 10 \mathrm{mg} \\
\text { Estradiol valerate } 4 \mathrm{mg}\end{array}$ & $\begin{array}{l}\text { - } \\
\text { Prasterone } \\
\text { enanthate } 200 \mathrm{mg}\end{array}$ & Office & $\begin{array}{l}\uparrow \text { systolic BP } \\
\uparrow \text { diastolic BP }\end{array}$ \\
\hline Jespersen 105 & 1993 & 24 & Oral & $\begin{array}{l}E 2 \\
E 2+E I\end{array}$ & $\begin{array}{l}- \\
\text { NETA }\end{array}$ & Office & $\begin{array}{l}\downarrow \text { systolic BP } \\
=\text { diastolic BP }\end{array}$ \\
\hline van der Mooren'1 & 1996 & 99 & Oral & E2 & DYD & Office & $\begin{array}{l}\uparrow \text { systolic BP } \\
\uparrow \text { diastolic BP }\end{array}$ \\
\hline Harvey ${ }^{106}$ & 2000 & 14 & Oral & CEE $0.3,0.625,1.25 \mathrm{mg}$ & MPA $10 \mathrm{mg}$ & Office & $\downarrow \mathrm{BP}$ \\
\hline Mueck $^{102}$ & 2000 & 13,190 & Oral & CEE $0.3,0.625,1.25 \mathrm{mg}$ & MPA $10 \mathrm{mg}$ & Office & $\begin{array}{l}\downarrow \text { systolic BP } \\
\downarrow \text { diastolic BP }\end{array}$ \\
\hline Foidart $^{108}$ & 1991 & 92 & $\begin{array}{l}\text { Transdermal + } \\
\text { Oral }\end{array}$ & E2 $50 \mu g$ & MPA $10 \mathrm{mg}$ & Office & $\begin{array}{l}=\text { diastolic BP } \\
=\text { systolic BP }\end{array}$ \\
\hline Sumino 107 & 2003 & 31 & Oral & CEE $0.625 \mathrm{mg}$ & MPA $2.5 \mathrm{mg}$ & Office & $=\mathrm{BP}$ \\
\hline Kaya ${ }^{110}$ & 2006 & 66 & Oral & E2 I mg & DYD $10 \mathrm{mg}$ & $24-h$ & $\begin{array}{l}\downarrow \text { systolic BP } \\
\downarrow \text { diastolic BP } \\
\downarrow \text { mean BP }\end{array}$ \\
\hline Wong'"I & 2005 & 34 & Oral & E2 & Norgestrel & $24-h$ & $\downarrow$ daily mean BP \\
\hline Affinito 112 & 2001 & 60 & Transdermal & E2 $50 \mu \mathrm{g}$ & MPA $10 \mathrm{mg}$ & 24-h & $\begin{array}{l}\downarrow \text { diastolic BP } \\
\downarrow \text { systolic BP }\end{array}$ \\
\hline Szekacs ${ }^{1 / 4}$ & 2000 & 30 & Transdermal & E2 $50 \mu \mathrm{g}$ & Norgestrel & $24-h$ & $\begin{array}{l}\downarrow \text { diastolic BP } \\
\downarrow \text { systolic BP }\end{array}$ \\
\hline
\end{tabular}

Abbreviations: 24-h, 24-hour; BP, blood pressure; CEE, conjugated equine estrogen; DYD, dihydrogesterone; EI, estrone; E2, estradiol; im, intramuscular; MPA, medroxyprogesterone acetate; NETA, norethisterone acetate; $\downarrow$, decrease; $\uparrow$, increase; =, no change, - , none. 


\section{HT with estrogens plus progestins in hypertensive women}

A revision of case-control and cross-sectional studies published between 1960 and 2004 reported that HT, performed with either oral or transdermal estrogen, does not consistently increase BP. ${ }^{102}$ In the Italian Climacteric Research Group Study (ICARUS), an observational investigation on 9,309 women, HT use was associated with significantly lower BP values in both normotensive and hypertensive women. ${ }^{103}$ In a randomized double-blind placebo-controlled trial performed in 55 postmenopausal women with mild to moderate hypertension, $4 \mathrm{mg}$ and $10 \mathrm{mg}$ of E2 valerate plus $200 \mathrm{mg}$ prasterone enanthate, administered for 3 months, did not induce any change of BP (Table 3). ${ }^{104}$ Jespersen et al investigated the effects of a 6-month treatment with E2 either alone or in sequential association with NETA on 24 postmenopausal women (12 normotensive and 12 hypertensive). In normotensive women, HT did not significantly modify systolic or diastolic BP. However, in hypertensive women systolic BP fell significantly during the treatment with either E2 or E2 plus NETA. ${ }^{105}$

On the other hand, the administration of oral E2 plus DYD caused an increase of 6.8 and $8.6 \mathrm{mmHg}$ of systolic and diastolic BP, respectively, in a group of 99 hypertensive women. ${ }^{91}$ Fourteen postmenopausal women with grade 1-2 hypertension were enrolled in a double blind crossover study. There were four randomized treatment phases, each lasting 4 weeks: CEE $0.3 \mathrm{mg}$, CEE $0.625 \mathrm{mg}$, CEE $1.25 \mathrm{mg}$ and placebo. Each subject also received MPA (10 mg for 14 days). In hypertensive postmenopausal women, HT exerted a variable effect on BP that was dependent on CEE dose. The "lower" and "middle" doses of CEE produced a small reduction of $\mathrm{BP}$, which tended to reverse with the "higher" CEE dose. ${ }^{106}$

Studies with transdermal estradiol and office BP measurement do show either a neutral or BP lowering effect (Table 3). A study was performed on 13,910 post-menopausal women, some of whom $(n=1,516)$ were taking transdermal E2 $(0.025$, 0.05 , and $0.01 \mathrm{mg}$ daily) with or without progestin (NETA 47.2\%, MPA 23.8\%, medrogestone 10.8\%, CMA 2.0\%, or DYD $1.5 \%$ ). After 2 months of treatment there was no effect of treatments on BP of normotensive women, while a decrease of office systolic and diastolic BP was observed in hypertensive women $(2-3 \mathrm{mmHg})$. In women with baseline diastolic BP higher than $100 \mathrm{mmHg}$, systolic BP decreased $7 \mathrm{mmHg}$ and diastolic BP decreased $9 \mathrm{mmHg} .{ }^{107}$ In another study performed on 92 hypertensive postmenpausal women, the 6-month administration of transdermal E2 plus $10 \mathrm{mg}$
MPA did not cause any significant variation of office systolic and diastolic BP. ${ }^{108}$

Studies with 24-hour ambulatory BP monitoring report more consistent evidence of a BP lowering effect exerted by HT (Table 3 ). In one study performed on 31 hypertensive women, CEE in doses of $0.625 \mathrm{mg}$ per day did not modify 24-hour ambulatory BP. ${ }^{109}$ However, in two other studies performed with oral E2, a decrease of 24-hour BP was observed during treatment. In a 12-month prospective study, 66 postmenopausal women with mild to moderate hypertension were randomly assigned to receive $1 \mathrm{mg}$ /day micronized E2 sequentially combined with MPA $10 \mathrm{mg} /$ day, or no therapy. A significant fall in 24-hour systolic, diastolic, and mean BP was observed, with decreases in both daytime and nighttime ambulatory BP. ${ }^{110}$ A positive effect of oral HT on BP was also described in a Canadian study showing that, in non-dipper individuals, HT significantly lowers daytime $\mathrm{BP}$ and induces a smaller nocturnal BP reduction than in dippers. Daytime diastolic BP was significantly and inversely related to duration of HT use. ${ }^{11}$

Studies with transdermal estradiol consistently show a reduction of BP during treatment (Table 3). In a study performed on 60 hypertensive women, transdermal E2 after 3 and 6 months significantly decreased systolic and diastolic daytime BP. ${ }^{112}$

By evaluating the different effect of estrogen on daytime and nighttime BP, it seems to emerge that, in normotensive women, the effect of estrogen is confined mainly to nighttime, with a magnification of the nocturnal BP pressure decline. ${ }^{111}$ In hypertensive women, however, reduction of BP induced by estrogen is more evident during the day. ${ }^{112,113}$ Indeed, a prospective study performed on 34 postmenopausal women 53 years of age with hypertension found that treatment with a cyclic combination of transdermal estradiol and norgestrel for 19 weeks significantly decreases daily systolic and diastolic BP. ${ }^{114}$

\section{HT with progestins in hypertensive women}

Studies dealing with the effect of progestins in hypertensive postmenopausal women were mainly limited to the investigation of DRSP (Table 3). In a randomized double-blind multicentric study performed in hypertensive postmenopausal women, the association of $3 \mathrm{mg}$ DRSP with $1 \mathrm{mg}$ of oral E2 significantly lowered both office and 24-hour systolic BP. ${ }^{95}$ The same authors reported a decrease of 6.1 and $4.7 \mathrm{mmHg}$ of daily systolic BP during the addition to E2 of 3 or $2 \mathrm{mg}$ of DRSP, respectively. ${ }^{96}$ Lately, the same 
authors evaluated the effects of DRSP on early morning BP of mild and slight hypertensive women. The association of $3 \mathrm{mg}, 2 \mathrm{mg}$, or $1 \mathrm{mg}$ of DRSP with E2 significantly reduced early morning systolic BP. In this study, modifications induced by E2 alone were not significantly different from those observed with placebo. The reduction of early morning BP was related to the dose of DRSP, higher doses being associated with greater effects both in systolic and diastolic BP. The magnitude of these effects is similar to that reported for anti-hypertensive medicines. The fact that they are confined to the night is probably related to the major effect of the renin-angiotensin system at night. ${ }^{97}$ DRSP (3 $\mathrm{mg}$ ), associated with enalapril and administered for two weeks in 24 healthy, non-smoking postmenopausal women, decreased significantly systolic and diastolic BP in comparison to placebo. ${ }^{115}$ Similarly, a multicentric study on 230 hypertensive women showed that the association of DRSP with angiotensin-converting-enzyme (ACE) inhibitors or angiotensin II antagonists induces a significant decrease of BP in comparison to placebo. ${ }^{116}$

\section{Conclusion}

The relationship between menopause, hormonal status, age, and BP is not clearly defined. Both estrogens and progestins may directly influence vasodilation, but their effect may be additive or antagonist. In vivo studies also indicate that estrogens may activate other mechanisms that regulate BP, such as catecholamines or renin-angiotensin-aldosterone systems. Some clinical trials which mainly address blood pressure modification as a secondary endpoint of the trial have shown some negative effects of oral estrogens on office BP. This is particularly evident in trials enrolling women several years after menopause, and with the use of oral CEE. The data are more convincing and reassuring when results obtained with 24-hour BP monitoring are considered. These studies are much smaller in terms of sample size but more accurate and usually performed in recently postmenopausal women. These studies do not show major negative effects of oral estrogen in the control of BP. Furthermore, they consistently show a reduction of BP with the use of transdermal estradiol. The effect appears to be evident both in normotensive and hypertensive postmenopausal women. Most of the progestins tested either do not affect or favor the hypotensive effect of estrogens. Among the progestins, DRSP appears to provide the best anti-hypertensive effects.

\section{Disclosure}

The authors report no conflicts of interest in this work.

\section{References}

1. Kearney PM, Whelton M, Reynolds K, Muntner P, Whelton PK, He J. Global burden of hypertension: analysis of worldwide data. Lancet. 2005;365(9455):217-223.

2. Franklin SS, Larson MG, Khan SA, et al. Does the relation of blood pressure to coronary heart disease risk change with aging? The Framingham Heart Study. Circulation. 2001;103:1245-1249.

3. World Health Organization. World Health Statistics. A Snapshot of Global Health. Geneva: World Health Organization; 2012. Available from: http://apps.who.int/iris/bitstream/10665/70889/1/WHO_IER_ HSI_12.1_eng.pdf. Accessed June 23, 2014.

4. Go AS, Mozaffarian D, Roger VL et al. Heart disease and stroke statistics - 2013 update: a report from the American Heart Association. Circulation. 2013;127:e6-e245.

5. Dubey RK, Oparil S, Imthurn B, Jackson EK. Sex hormones and hypertension. Cardiovasc Res. 2002;53(3):688-708.

6. Staessen J, Bulpitt CJ, Fagard R, Lijnen P, Amery A. The influence of menopause on blood pressure. J Hum Hypertens. 1989;3(6): $427-433$.

7. Scuteri A, Bos AJ, Brant LJ, Talbot L, Lakatta EG, Fleg JL. Hormone replacement therapy and longitudinal changes in blood pressure in postmenopausal women. Ann Intern Med. 2001;135(4):229-238.

8. Amigoni S, Morelli P, Parazzini F, Chatenoud L. Determinants of elevated blood pressure in women around menopause: results from a cross-sectional study in Italy. Maturitas. 2000;34(1):25-32.

9. Zanchetti A, Facchetti R, Cesana GC, Modena MG, Pirrelli A, Sega R. Menopause-related blood pressure increase and its relationship to age and body mass index: the SIMONA epidemiological study. J Hypertens. 2005;23(12):2269-2276.

10. Cifkova R, Pitha J, Lejskova M, Lanska V, Zecova S. Blood pressure around the menopause: a population study. J Hypertens. 2008;26(10):1976-1982.

11. Cagnacci A, Zanin R, Cannoletta M, Generali M, Caretto S, Volpe A. Menopause, estrogens, progestins, or their combination on body weight and anthropometric measures. Fertil Steril. 2007;88(6):1603-1608.

12. Cagnacci A, Cannoletta M, Palma F, Zanin R, Xholli A, Volpe A. Menopausal symptoms and risk factors for cardiovascular disease in postmenopause. Climacteric. 2012;15(2):157-162.

13. Toth MJ, Tchernof A, Sites CK, Poehlman ET. Effect of menopausal status on body composition and abdominal fat distribution. Int J Obes Relat Metab Disord. 2000;24(2):226-231.

14. Casiglia E, d'Este D, Ginocchio G, et al. Lack of influence of menopause on blood pressure and cardiovascular risk profile: a 16-year longitudinal study concerning a cohort of 568 women. J Hypertens. 1996;14(6):729-736.

15. Lee JS, Hayashi K, Mishra G, Yasui T, Kubota T, Mizunuma H. Independent association between age at natural menopause and hypercholesterolemia, hypertension, and diabetes mellitus: Japan nurses' health study. J Atheroscler Thromb. 2013;20(2):161-169.

16. Casiglia E, Tikhonoff V, Caffi S, et al. Menopause does not affect blood pressure and risk profile, and menopausal women do not become similar to men. J Hypertens. 2008;26(10):1983-1992.

17. Vegeto E, Belcredito S, Etteri S, et al. Estrogen receptor-alpha mediates the brain antiinflammatory activity of estradiol. Proc Natl Acad Sci U S A. 2003;100(16):9614-9619.

18. Darblade B, Pendaries C, Krust A, et al. Estradiol alters nitric oxide production in the mouse aorta through the alpha-, but not beta-, estrogen receptor. Circ Res. 2002;90(4):413-419.

19. Geary GG, McNeill AM, Ospina JA, Krause DN, Korach KS, Duckles SP. Selected contribution: cerebrovascular nos and cyclooxygenase are unaffected by estrogen in mice lacking estrogen receptor-alpha. J Appl Physiol. 2001;91(5):2391-2399.

20. Chakrabarti S, Morton JS, Davidge ST. Mechanisms of estrogen effects on the endothelium: an overview. Can J Cardiol. 2014;30(7):705-712.

21. Gustafsson $\mathrm{J} \AA$. What pharmacologists can learn from recent advances in estrogen signalling Trends Pharmacol Sci. 2003;24(9):479-485. 
22. Cruz MN, Agewall S, Schenck-Gustafsson K, Kublickiene K. Acute dilatation to phytoestrogens and estrogen receptor subtypes expression in small arteries from women with coronary heart disease. Atherosclerosis. 2008;196(1):49-58.

23. Wellman GC, Bonev AD, Nelson MT, Brayden JE. Gender differences in coronary artery diameter involve estrogen, nitric oxide, and Ca(2+)-dependent K+ channels. Circ Res. 1996;79(5):1024-1030.

24. Freay AD, Curtis SW, Korach KS, Rubanyi GM. Mechanism of vascular smooth muscle relaxation by estrogen in depolarized rat and mouse aorta. Role of nuclear estrogen receptor and $\mathrm{Ca} 2+$ uptake. Circ Res. 1997;81(2):242-248

25. Crews K, Khalil RA. Gender-specific inhibition of $\mathrm{Ca} 2+$ entry mechanisms of arterial vasoconstriction by sex hormones. Clin Exp Pharmacol Physiol. 1999;26(9):707-715.

26. Wenner MM, Stachenfeld NS. Blood pressure and water regulation: understanding sex hormone effects within and between men and women. J Physiol. 2012;590(Pt 23):5949-5961.

27. Wassmann K, Wassmann S, Nickenig G. Progesterone antagonizes the vasoprotective effect of estrogen on antioxidant enzyme expression and function. Circ Res. 2005;97(10):1046-1054.

28. Pines A, Fisman EZ, Drory Y, et al. The effects of sublingual estradiol on left ventricular function at rest and exercise in postmenopausal women an echocardiographic assessment. Menopause. 1998;5(2):79-85.

29. Reis SE, Glothe ST, Blumenthal RS, et al. Ethinyl estradiol acutely attenuates abnormal coronary vasomotor responses to acetylcholine in postmenopausal women. Circulation. 1994;89(1):52-60.

30. Gilligan DM, Badar DM, Panza JA, Quyyumi AA, Cannon RO. Acute vascular effects of estrogen in postmenopausal women. Circulation. 1994;90(2):786-791.

31. Volterrani M, Rosano G, Coats A, Beale C, Collins P. Estrogen acutely increases peripheral blood flow in postmenopausal women. Am J Med. 1995;99(2):119-122.

32. Tagawa H, Shimokawa H, Tagawa T, Kuroiwa-Matsumoto M, Hirooka Y, Takeshita A. Short-term estrogen augments both nitric oxidemediated and nonnitric oxide-mediated endothelium-dependent forearm vasodilation in postmenopausal women. J Cardiovasc Pharmacol. 1997;30(4):481-488.

33. Al-Khalili F, Eriksson M, Landgren BM, Schenk-Gustafsson K. Effect of conjugated estrogen on peripheral flow-mediated vasodilation in postmenopausal women. Am J Cardiol. 1998;82(2):215-218.

34. Ciccone MM, Scicchitano P, Gesualdo M, et al. Systemic vascular hemodynamic changes due to 17 - $\beta$-estradiol intranasal administration. $J$ Cardiovasc Pharmacol Ther. 2013;18(4):354-358.

35. Lieberman EH, Gerhard MD, Uehata A, et al. Estrogen improves endothelium-dependent, flow-mediated vasodilation in postmenopausal women. Ann Intern Med. 1994;121(12):936-941.

36. Bush DE, Jones CE, Bass KM, Walters GK, Bruza JM, Ouyang P. Estrogen replacement reverses endothelial dysfunction in postmenopausal women. Am J Med. 1998;104(6):552-558.

37. Gerhard M, Walsh BW, Tawakol A, et al. Estradiol therapy combined with progesterone and endothelium-dependent vasodilation in postmenopausal women. Circulation. 1998;98(12):1158-1163.

38. Pinto S, Virdis A, Ghiadono L, et al. Endogenous estrogen and acetylcholine-induced vasodilation in normotensive women Hypertension. 1997;29(1 Pt 2):268-263.

39. Sorensen KE, Dorup I, Hermann AP, Mosekilde L. Combined hormone replacement therapy does not protect women against the age-related decline in endothelium-dependent vasomotor function. Circulation. 1998;97(13):1234-1238

40. Cagnacci A, Modena MG, Malmusi S, Muia N, Volpe A. Effect of prolonged administration of transdermal estradiol on flow-mediated endothelium-dependent and endothelium-independent vasodilation in healthy postmenopausal women. Am J Cardiol. 1999;84(3):367-370.

41. Oneda B, Cardoso CG Jr, Foriaz CL, et al. Effects of estrogen therapy and aerobic training on sympathetic activity and hemodynamics in healthy postmenopausal women: a double-blind randomized trial. Menopause. 2014;21(4):369-375.
42. Novella S, Dantas AP, Segarra G, et al. Gathering of aging and estrogen withdrawal in vascular dysfunction of senescent accelerated mice. Exp Gerontol. 2010;45(11):868-874.

43. Best PJ, Berger PB, Miller VM, Lerman A. The effect of estrogen replacement therapy on plasma nitric oxide and endothelin-1 levels in postmenopausal women. Ann Intern Med. 1998;128(4):285-288.

44. Imthurn B, Rosselli M, Jaeger AW, Keller PJ, Dubey RK. Differential effects of hormone-replacement therapy on endogenous nitric oxide (nitrite/nitrate) levels in postmenopausal women substituted with 17 beta-estradiol valerate and cyproterone acetate or medroxyprogesterone acetate. J Clin Endocrinol Metab. 1997;82(2):388-394.

45. Rosselli M, Imthurn B, Keller PJ, Jackson EK, Dubey RK. Circulating nitric oxide (nitrite/nitrate) levels in postmenopausal women substituted with 17 beta-estradiol and norethisterone acetate. A two-year follow-up study. Hypertension. 1995;25(4 Pt 2):848-853.

46. Ylikorkala O, Cacciatore B, Paakkari I, Tikkanen MJ, Viinikka L, Toivonen J. The long-term effects of oral and transdermal postmenopausal hormone replacement therapy on nitric oxide, endothelin-1, prostacyclin, and thromboxane. Fertil Steril. 1998;69(5): 883-888.

47. Viinikka L, Orpana A, Puolakka J, Pyörälä T, Ylikorkala O. Different effects of oral and transdermal hormonal replacement on prostacyclin and thromboxane A2. Obstet Gynecol. 1997;89(1):104-107.

48. Morey AK, Razandi M, Pedram A, Hu RM, Prins BA, Levin ER. Oestrogen and progesterone inhibit the stimulated production of endothelin-1. Biochem J. 1998;330(Pt 3):1097-1105.

49. Reckelhoff JF, Fortepiani LA. Novel mechanisms responsible for postmenopausal hypertension. Hypertension. 2004;43(5):918-923.

50. Dubey RK, Oparil S, Imthurn B, Jackson EK. Sex hormones and hypertension. Cardiovasc Res. 2002;53(3):688-708.

51. Schunkert H, Danser AH, Hense HW, Derkx FH, Kurzinger S, Riegger GA. Effects of estrogen replacement therapy on the renin-angiotensin system in postmenopausal women. Circulation. 1997;95(1):39-45.

52. Ylikorkala O, Orpana A, Puolakka J, Pyörälä T, Viinikka L. Postmenopausal hormonal replacement decreases plasma levels of endothelin-1. J Clin Endocrinol Metab. 1995;80(11):3384-3387.

53. Nickenig G, Baumer AT, Grohe C, et al. Estrogen modulates AT1 receptor gene expression in vitro and in vivo. Circulation. 1998;97(22):2197-3001.

54. Menozzi R, Cagnacci A, Zanni AL, Bondi M, Volpe A, Del Rio G. Sympathoadrenal response of postmenopausal women prior and during prolonged administration of estradiol. Maturitas. 2000;34(3): 275-281.

55. Cagnacci A, Zanni AL, Veneri MG, Menozzi R, Volpe A, Del Rio G. Influence of exogenous melatonin on catecholamine levels in postmenopausal women prior and during oestradiol replacement. Clin Endocrinol (Oxf). 2000;53(3):367-372.

56. Pimienta E. Hypertension in women. Hypertension Research. 2012;35(2):148-152.

57. Fung MM, Poddar S, Bettencourt R, Jassal SK, Barrett-Connor E. A cross-sectional and 10-year prospective study of postmenopausal estrogen therapy and blood pressure, renal function, and albuminuria: the Rancho Bernardo Study. Menopause. 2011;18(6):629-637.

58. Anderson GL, Limacher M, Assaf AR, et al. Effects of conjugated equine estrogen in postmenopausal women with hysterectomy: the Women's Health Initiative randomized controlled trial. JAMA. 2004;291(14):1701-1712.

59. Wren BG, Routledge DA. Blood pressure changes: oestrogens in climacteric women. Med J Aust. 1981;2(10):528-531.

60. Wren BG, Routledge AD. The effect of type and dose of oestrogen on the blood pressure of post-menopausal women. Maturitas. 1983;5(2):135-142.

61. Steiner AZ, Hodis HN, Lobo RA, Shoupe D, Xiang M, Mack WJ. Postmenopausal oral estrogen therapy and blood pressure in normotensive and hypertensive subjects: the Estrogen in the Prevention of Atherosclerosis Trial. Menopause. 2005;12(6):728-733. 
62. Cardoso CG Jr, Rosas FC, Oneda B, et al. Aerobic training abolishes ambulatory blood pressure increase induced by estrogen therapy: a double blind randomized clinical trial. Maturitas. 2011;69(2):189-194.

63. Akkad AA, Halligan AW, Abrams K, al-Azzawi F. Differing responses in blood pressure over 24 hours in normotensive women receiving oral or transdermal estrogen replacement therapy. Obstet Gynecol. 1997;89(1):97-103.

64. Vongpatanasin W, Tuncel M, Mansour Y, Arbique D, Victor RG. Transdermal estrogen replacement therapy decreases sympathetic activity in postmenopausal women. Circulation. 2001;103(24): 2903-2908.

65. Cagnacci A, Rovati L, Zanni A, Malmusi S, Facchinetti F, Volpe A. Physiological doses of estradiol decrease nocturnal blood pressure in normotensive postmenopausal women. Am J Physiol. 1999;276(4 Pt 2): H1355-H1360.

66. Driul L, Stella A, Marchesoni D. Twenty-four hour ambulatory blood pressure in postmenopausal smokers and non-smokers on hormone therapy. Int J Gynaecol Obstet. 2005;90(1):82-83.

67. Windler E, Zyriax BC, Eidenmüller B, Boeing H. Hormone replacement therapy and risk for coronary heart disease. Data from the CORA-study - A case-control study on women with incident coronary heart disease. Maturitas. 2007;57(3):239-246.

68. Scuteri A, Bos AJ, Brant LJ, Talbot L, Lakatta EG, Fleg JL. Hormone replacement therapy and longitudinal changes in blood pressure in postmenopausal women. Ann Intern Med. 2001;21;135(4): 229-238.

69. Hassager C, Christiansen C. Blood pressure during oestrogen/ progestogen substitution therapy in healthy post-menopausal women. Maturitas. 1988;9(4):315-323.

70. The Writing Group for the PEPI Trial. Effects of estrogen or estrogen/ progestin regimens on heart disease risk factors in postmenopausal women. The Postmenopausal Estrogen/Progestin Interventions (PEPI) Trial. JAMA. 1995;273(3):199-208.

71. Vestergaard P, Hermann AP, Stilgren L, et al. Effects of 5 years of hormonal replacement therapy on menopausal symptoms and blood pressure - a randomised controlled study. Maturitas. 2003;46(2): $123-132$.

72. Chiu CL, Lujic S, Thornton C, et al. Menopausal hormone therapy is associated with having high blood pressure in postmenopausal women: observational cohort study. PLoS One. Epub July 11, 2012.

73. Wassertheil-Smoller S, Anderson G, Psaty BM, et al. Hypertension and its treatment in postmenopausal women: baseline data from the Women's Health Initiative. Hypertension. 2000;36(5):780-789.

74. Grady D, Herrington D, Bittner R, et al. Cardiovascular disease outcomes during 6.8 years of hormone therapy. Heart and Estrogen/progestin Replacement Study follow-up (HERS II). JAMA. 2002;288(1):49-57.

75. van Ittersum FJ, van Baal WM, Kenemans P, et al. Ambulatory not office - blood pressures decline during hormone replacement therapy in healthy postmenopausal women. Am J Hypertens. 1998;11(10):1147-1152.

76. Harvey PJ, Wing LM, Savage J, Molloy D. The effects of different types and doses of oestrogen replacement therapy on clinic and ambulatory blood pressure and the renin-angiotensin system in normotensive postmenopausal women. J Hypertens. 1999;17(3):405-411.

77. Sørensen MB, Rasmussen V, Jensen G, Ottesen B. Temporal changes in clinic and ambulatory blood pressure during cyclic postmenopausal hormone replacement therapy. J Hypertens. 2000;18(10): 1387-1391

78. Manwaring P, Morfis L, Diamond T, Howes LG. Effects of hormone replacement therapy on ambulatory blood pressure and vascular responses in normotensive women. Blood Press. 2000;9(1):22-27.

79. Cacciatore B, Paakkari I, Hasselblatt R, et al. Randomized comparison between orally and transdermally administered hormone replacement therapy regimens of long-term effects on 24-hour ambulatory blood pressure in postmenopausal women. Am J Obstet Gynecol. 2001;184(5): 904-909.
80. Paakari I, Hasselblatt R, Nieminen MS, et al. Comparison of the effect of transdermal and oral HRT on ambulatory blood pressure in postmenopausal women. Maturitas. 1997;27(1001):98.

81. Pripp U, Hall G, Csemiczky G, Eksborg S, Landgren BM, SchenckGustafsson K. A randomized trial on effects of hormone therapy on ambulatory blood pressure and lipoprotein levels in women with coronary artery disease. J Hypertens. 1999;17(10):1379-1386.

82. Zacharieva S, Kirilov G, Kalinov K, et al. Effect of different hormone replacement therapy regimens on circadian blood pressure profile and active renin in postmenopausal women. Gynecol Endocrinol. 2002;16(6):461-467.

83. Seely EW, Walsh BW, Gerhard MD, Williams GH. Estradiol with or without progesterone and ambulatory blood pressure in postmenopausal women. Hypertension. 1999;33(5):1190-1194.

84. Seeger H, Mueck AO, Teichmann AT, Lippert TH. Effect of sequential estrogen/progestin treatment on biochemical vasoactive markers in postmenopausal women comparing oral and transdermal application. Clin Exp Obstet Gynecol. 2000;27(1):17-20.

85. Kuhl H. [Vascular effects of gestagens - biochemistry versus epidemiology.] Zentralbl Gynakol. 1999;121(2):67-78. German [with English abstract].

86. Rylance PB, Brincat M, Lafferty K, et al. Natural progesterone and antihypertensive action. Br Med J. 1985;290(6461):13-14.

87. Deuringer FU, Mueck AO, Mueck S, Seeger H, Wallwiener D. Progestin effect on blood pressure during combination with transdermal estradiol - chlormadinone acetate vs norethisterone acetate. In: Aso T, Yanaihara T, Taketani Y, Suda T, Tanaka H, Maehara S, editors. Ninth International Menopause Society World Congress on the Menopause. Bologna: Monduzzi Editore S.p.A; 2000:177-181.

88. Mueck AO, Seeger H, Gräser T, Deuringer FU, Oettel M, Lippert TH. Chlormadinone acetate vs norethisterone acetate sequentially combined with oral or transdermal estradiol replacement. NS Arch Pharmacol Toxicol. 1997;356:R5-R6.

89. Mueck AO, Gräser T, Seeger H, et al. Is there a dose-dependent effect of dienogest, continuously combined with estradiol valerate, on blood pressure? Experimental and Clinical Endocrinol Diabetes. 1998;106(1):S36.

90. Mueck AO, Seeger H, Lüdtke R, Gräser T, Wallwiener D. Effect on biochemical vasoactive markers during postmenopausal hormone replacement therapy: estradiol vs estradiol/dienogest. Maturitas. 2001;38(3):305-313.

91. van der Mooren MJ. The influence of postmenopausal oestradioldydrogesterone therapy on blood pressure. Maturitas. 1996; 27(Suppl 1):99-100.

92. Kessel H, Kamp O, Kenemans P, et al. Effects of 15 months of 17 betaestradiol and dydrogesterone on systolic cardiac function according to quantitative and Doppler echocardiography in healthy postmenopausal women. Am J Obstet Gynecol. 2001;184(5):910-916.

93. Harvey PJ, Molloy D, Upton J, Wing LM. Dose response effect of cyclical medroxyprogesterone on blood pressure in postmenopausal women. J Hum Hypertens. 2001;15(5):313-321.

94. Archer DF. Drospirenone, a progestin with added value for hypertensive postmenopausal women. Menopause. 2007;14(3 Pt 1):352-354.

95. White WB, Pitt B, Preston RA, Hanes V. Antihypertensive effects of drospirenone with 17 beta-estradiol, a novel hormone treatment in postmenopausal women with stage 1 hypertension. Circulation. 2005;112(13):1979-1984

96. White WB, Hanes V, Chauhan V, Pitt B. Effects of a new hormone therapy, drospirenone and 17-beta-estradiol, in postmenopausal women with hypertension. Hypertension. 2006;48(2):246-253.

97. White WB, Hanes V, Mallareddy M, Chauhan V. Effects of the hormone therapy, drospirenone and 17-beta estradiol, on early morning blood pressure in postmenopausal women with hypertension. J Am Soc Hypertens. 2008;2(1):20-27.

98. Gambacciani M, Rosano G, Cappagli B, Pepe A, Vitale C, Genazzani AR. Clinical and metabolic effects of drospirenone-estradiol in menopausal women: a prospective study. Climacteric. 2011;14(1):18-24. 
99. Battaglia C, Cianciosi A, Mancini F, et al. Angeliq versus Activelle in normotensive postmenopausal women: a prospective, randomized pilot study. Menopause. 2009;16(4):803-809.

100. Luotola H. Blood pressure and hemodynamics in postmenopausal women during estradiol-17 beta substitution. Ann Clin Res. 1983; 15 Suppl 38:1-121.

101. Mercuro G, Zoncu S, Piano D, et al. Estradiol-17beta reduces blood pressure and restores the normal amplitude of the circadian blood pressure rhythm in postmenopausal hypertension. Am J Hypertens. 1998;11(8 Pt 1):909-913.

102. Mueck AO, Seeger H. Effect of hormone therapy on BP in normotensive and hypertensive postmenopausal women. Maturitas. 2004;49(3):189-203.

103. de Aloysio D, Gambacciani M, Meschia M, et al. The effect of menopause on blood lipid and lipoprotein levels. The Icarus Study Group. Atherosclerosis. 1999;147(1):147-153.

104. Kornhauser C, Malacara JM, Garay ME, Pérez-Luque EL. The effect of hormone replacement therapy on blood pressure and cardiovascular risk factors in menopausal women with moderate hypertension. J Hum Hypertens. 1997;11(7):405-411.

105. Jespersen CM, Arnung K, Hagen C, et al. Effects of natural oestrogen therapy on blood pressure and renin-angiotensin system in normotensive and hypertensive menopausal women. $J$ Hypertens. 1983;1(4):361-364.

106. Harvey PJ, Molloy D, Upton J, Wing LM. Dose response effect of conjugated equine oestrogen on blood pressure in postmenopausal women with hypertension. Blood Press. 2000;9(5): 275-282.

107. Mueck AO, Deuringer FU, Seeger H, Wallwiener D. Transdermal estradiol/oral progestin: blood pressure in 13910 patients. Maturitas. 2000;35:S63.
108. Foidart JM. Effects of estraderm TTS 50 plus medroxyprogesterone acetate on blood pressure in hypertensive postmenopausal women. In: Samsioe G, editor. Cardiovascular Disease and HRT. New Perspectives. UK: Parthenon; 1991:41-44.

109. Sumino H, Ichikawa S, Kumakura H, et al. Effects of hormone replacement therapies on office and ambulatory blood pressure in Japanese hypertensive postmenopausal women. Hypertens Res. 2003;26(5):369-376.

110. Kaya C, Dinçer Cengiz S, Cengiz B, Akgün G. The long-term effects of low-dose 17beta-estradiol and dydrogesterone hormone replacement therapy on 24-h ambulatory blood pressure in hypertensive postmenopausal women: a 1-year randomized, prospective study. Climacteric. 2006;9(6):437-445.

111. Wong J, Wong S, Handa P, Abbott C. Hormone replacement use, arterial distensibility, cardiac structure and circadian blood pressure profile in menopausal women. Blood Press. 2005;14(1):12-20.

112. Affinito P, Palomba S, Bonifacio $M$ et al. Effects of hormonal replacement therapy in postmenopausal hypertensive patients Maturitas. 2001;40(1):75-83.

113. Schulman IH, Aranda P, Raij L, Veronesi M, Aranda FJ, Martin R. Surgical menopause increases salt sensitivity of blood pressure. Hypertension. 2006;47(6):1168-1174.

114. Szekacs B, Vajo Z, Acs N, et al. Hormone replacement therapy reduces mean 24-hour blood pressure and its variability in postmenopausal women with treated hypertension. Menopause. 2000;7(1):31-35.

115. Preston RA, Alonso A, Panzitta D, Zhang P, Karara AH. Additive effect of drospirenone/17-beta-estradiol in hypertensive postmenopausa women receiving enalapril. Am J Hypertens. 2002;15(9):816-822.

116. Preston RA. Comparative effects of conventional vs novel hormone replacement therapy on blood pressure in postmenopausal women. Climacteric. 2009;12 Suppl 1:66-70.
International Journal of Women's Health

\section{Publish your work in this journal}

The International Journal of Women's Health is an international, peerreviewed open-access journal publishing original research, reports, editorials, reviews and commentaries on all aspects of women's healthcare including gynecology, obstetrics, and breast cancer. The manuscript management system is completely online and includes

\section{Dovepress}

a very quick and fair peer-review system, which is all easy to use. Visit http://www.dovepress.com/testimonials.php to read real quotes from published authors. 